\title{
RESPON PEMBERIAN PUPUK UREA DAN URINE SAPI TERHADAP PERTUMBUHAN BIBIT KELAPA SAWIT (Elaeis guineensis Jacq.) DI PEMBIBITAN AWAL
}

\author{
Asari Nasution \\ Alumnus Program Studi Budidaya Perkebunan, Fakultas Pertanian dan Peternakan, Universitas Tjut Nyak \\ Dhien, Medan 20123, Sumatera Utara, Indonesia.
}

\author{
Ahmad Nadhira* \\ Program Studi Agroteknologi, Fakultas Pertanian dan Peternakan, Universitas Tjut Nyak Dhien, Medan \\ 20123, Sumatera Utara, Indonesia. Email: ahmadnadhira@gmail.com \\ Tengku Boumedine Hamid Zulkifli \\ Program Studi Agroteknologi, Fakultas Pertanian dan Peternakan, Universitas Tjut Nyak Dhien, Medan \\ 20123, Sumatera Utara, Indonesia.
}

\begin{abstract}
Abstrak
Penelitian ini bertujuan untuk mengetahui pemberian respon pemberian pupuk urea dan urine sapi dapat meningkatkan pertumbuhan vegetatif bibit kelapa sawit (Elaeis guineensis Jacq) di pembibitan awal. Penelitian ini dilaksanakan pada September sampai Desember 2015 di Kebun Masyarakat Kelurahan Sari Rejo, Kecamatan Medan Polonia. Metode penelitian menggunakan rancangan acak kelompok faktorial dengan dua taraf yaitu: faktor pertama: pemberian pupuk urea dengan 3 taraf: $\mathrm{P}_{0}=$ tanpa pupuk urea; $\mathrm{P}_{1}=$ pupuk urea $2 \mathrm{~g} /$ polibag; $\mathrm{P}_{2}=$ pupuk urea $4 \mathrm{~g} /$ polibag. Faktor kedua: pemberian urine sapi 4 taraf: $\mathrm{U}_{0}=$ tanpa urine sapi; $\mathrm{U}_{1}=$ urine sapi $80 \mathrm{ml} /$ polibag; $\mathrm{U}_{2}=$ urine sapi $160 \mathrm{ml} / \mathrm{polibag}$; $\mathrm{U}_{3}=$ urine sapi $240 \mathrm{ml} /$ polibag. Hasil penelitian menunjukkan bahwa pemberian pupuk urea dapat meningkatkan tinggi bibit tanaman kelapa sawit umur 11 MST dengan dosis 4 g/polibag memberikan tinggi bibit kelapa sawit tertinggi $21,17 \mathrm{~cm}$. Pemberian urine sapi belum dapat meningkatkan pertumbuhan bibit tanaman kelapa sawit. Interaksi antara pemberian pupuk urea dan urine sapi belum dapat meningkatkan pertumbuhan vegetatif bibit kelapa sawit di pembibitan awal.
\end{abstract}

Kata Kunci: kelapa sawit, urea, urine sapi, vegetatif

\section{PENDAHULUAN}

Tanaman kelapa sawit merupakan salah satu tanaman perkebunan yang memerlukan input hara cukup tinggi. Biaya produksi pupuk merupakan bagian terbesar dalam biaya pemeliharaan tanaman kelapa sawit. Pemupukan menjadi faktor penting dalam upaya mencapai produktivitas yang tinggi, terutama dalam memenuhi ketersediaan hara (Darmosakoro et al., 2007).

Menurut Lubis, (1992) untuk menunjang pertumbuhan bibit kelapa sawit yang berkualitas, sangat diperlukan pemupukan salah satunya karena bibit kelapa sawit memiliki pertumbuhan yang sangat cepat dan membutuhkan cukup banyak pupuk. Selain jumlah pupuk majemuk yang diperlukan banyak juga sulit diperoleh dan mahal. Penggunaan pupuk anorganik terus menerus juga dapat merusak lingkungan.

Pupuk urea adalah termasuk pupuk anorganik yang juga merupakan pupuk $\mathrm{N}$ (nitrogen). Urea termasuk pupuk yang higroskopis. Funsi utama pupuk urea adalah meningkatkan pertumbuhan tanaman dan hijau daun (Lingga \& Marsono, 2006)

Penelitian Djojosuwito, (2000) menyatakan bahwa penggunaan pupuk buatan pabrik secara terus menerus dapat mengakibatkan kandungan bahan organik tanah dan ketersediaan hara akan turun dengan cepat, tanah mudah mengalami kekeringan dan sukar diolah sehingga secara tidak langsung dapat menurunkan produktivitas tanah dalam jangka waktu tertentu.
Menurut Hadisuwito, (2007) pupuk organik cair merupakan salah satu alternative untuk mengurangi pemakaian pupuk anorganik yang diberikan melalui akar. Pupuk organik sangat bermanfaat bagi peningkatan produksi pertanian baik kualitas maupun kuantititas, mengurangi pencemaran lingkungan fdan meningkatkan kualitas lahan secara berkelanjutan.

Pupuk organik baik berbentuk padat maupun cair mempunyai fungsi yang penting yaitu untuk menggemburkan lapisan tanah permukaan top soil, meningkatkan populasi jasad renik, mempertinggi daya serap dan daya simpan air (Sutedjo, 1999; Anwar \& Suganda, 2006). Pupuk kandang cair merupakan pupuk yang diperoleh dari urine hewan atau ternak. Urine hewan yang digunakan sebagai pupuk kandang berwarna coklat dengan bau yang menyengat. Bau ini disebabkan oleh kandungan unsur nitrogen (Novizan, 2007). Menurut Lingga \& Marsono, (2006) kandungan hara dari urine sapi adalah N 1,00\%; P 0,50\%; K 1,50\%.

Mengingat pentingnya tanaman kelapa sawit sebagai tanaman perkebunan yang sangat penting serta mendapatkan perhatian serta prioritas dari pemerintah serta masyarakat Indonesia umumnya, dan urine sapi merupakan salah satu contoh pupuk organik cair yang diharapkan dapat digunakan sebagai pupuk alternatif untuk meningkatkan pertumbuhan bibit kelapa sawit. Tujuan penelitian untuk mengetahui respon pemberian pupuk urea dan urine sapi dalam meningkatkan pertumbuhan bibit kelapa sawit (Elaeis guineensis Jacq). 


\section{METODE}

\section{Tempat dan Waktu Penelitian}

Penelitian ini dilaksanakan pada September sampai Desember 2015 di Kebun Masyarakat Kelurahan Sari Rejo, Kecamatan Medan Polonia.

\section{Bahan dan Alat}

Tanah yang digunakan dalam penelitian ini adalah media tanah topsoil, baby polibag $10 \mathrm{~kg}$ ukuran lebar $25 \mathrm{~cm}$ ketebalan 0,15 mm, benih tanaman kelapa sawit D x P keluaran RISPA Medan, pupuk urea, TSP, $\mathrm{KCl}$. urine sapi, insektisida decis, herbisida roundup, fungisida dithane M-45. Alat yang digunakan: cangkul, gembor, label nama, alat tulis, plastik, ember, meteran, kalkulator, pompa air.

\section{Model Penelitian}

Penelitian dilakukan dengan menggunakan rancangan acak kelompok (RAK) faktorial dengan dua taraf yaitu: faktor pertama: pemberian pupuk urea dengan 3 taraf: $\mathrm{P}_{0}=$ tanpa pupuk urea; $\mathrm{P}_{1}=$ pupuk urea 2 g/polibag; $\mathrm{P}_{2}=$ pupuk urea $4 \mathrm{~g} /$ polibag. Faktor kedua: pemberian urine sapi 4 taraf: $\mathrm{U}_{0}=$ tanpa urine sapi; $\mathrm{U}_{1}=$ urine sapi $80 \mathrm{ml} /$ polibag; $\mathrm{U}_{2}=$ urine sapi $160 \mathrm{ml} /$ polibag; $\mathrm{U}_{3}=$ urine sapi $240 \mathrm{ml} /$ polibag. Data hasil pengamatan dianalisis dengan uji $\mathrm{F}$, apabila dalam uji statistik data diperoleh signifikan maka pengujian dilanjutkan dengan uji DMRT (Duncan Multiple Range Test).

\section{Persiapan Media}

Media tanam yang digunakan adalah tanah topsoil kemudian diayak dan dibersihkan dari sisa-sisa tumbuhan dan kotoran lainnya. Setelah itu dimasukkan kedalam baby polibag $10 \mathrm{~kg}$ ukuran lebar $25 \mathrm{~cm}$ dan tebal $0,15 \mathrm{~mm}$.

\section{Persiapan Lahan}

Lahan areal penelitian dibersihkan dari gulma dan tanaman lain yang tumbuh diatasnya kemudian lahan diolah dengan traktor dan dicangkul sampai siap tanam, kemudian dibuat petak-petak percobaan berukuran $90 \mathrm{~cm}$ x $60 \mathrm{~cm}$. Lahan penelitian dibuat naungan kemudian diatur sedemikian rupa sesuai dengan perlakuan. Setiap percobaan dalam satu plot dibatasi oleh parit drainase selebar $50 \mathrm{~cm}$, sedangkan jarak antar ulangan $100 \mathrm{~cm}$.

\section{Penanaman Kecambah}

Kecambah yang telah tumbuh diarea perkecambahan kemudian ditanam pada lubang yang telah disiapkan dipolibag yang telah terisi media tanah topsoil lahan. Kemudian tanah disekilingnya dipadatkan agar batang kecambah dapat berdiri tegak.

\section{Pemberian Pupuk Urea}

Pupuk yang diberikan adalah pupuk urea yang sesuai dengan perlakuan. Pemberian pupuk urea diberikan 2 kali yakni 4 dan 8 Minggu Setelah Tanam (MST).

\section{Pemberian Urine Sapi}

Pemberian urine sapi kemudian tanaman topsoil sesuai dengan perlakuan. Pemberian pupuk urine sapi diberikan 2 kali yakni 4 dan 8 MST.

\section{Analisis Tanah Sebelum Tanam}

Diambil sampel tanah untuk dianalisis beberapa karaktertistik kimia tanahnya. Hasil analisis tanah di lokasi penelitian menunjukkan bahwa $\mathrm{N}$-total $0,13 \%$; P-tersedia metode Bray-II sebesar 17,81 ppm; $\mathrm{pH} \mathrm{H}_{2} \mathrm{O}$ sebesar 5,57; C-organik sebesar 1,23\%; K-dd sebesar 0,11 me/100g; dan Ca-dd sebesar 4,31 me/100 g..

\section{Peubah Amatan}

Tinggi tanaman diukur mulai dari permukaan tanah (patok standar) sampai daun tertinggi yaitu yang tegak alami. Pengukuran dilakukan pada 3 tanaman sampel. Pengukuran luas daun dilakukan menggunakan alat leaf area meter dan dilaksanakan saat tanaman berumur 11 MST. Penimbangan bobot basah tanaman dilakukan pada akhir penelitian. Penimbangan ini dilaksanakan pada umur 11 minggu setelah tanam. Bobot kering diamati dengan menimbang tanaman yang terlebih dahulu dikeringanginkan, kemudian dimasukkan ke dalam oven selama 3 x 24 jam pada suhu $65^{\circ} \mathrm{C}$, Penimbangan ini dilaksanakan pada umur $11 \mathrm{MST}$.

\section{HASIL DAN PEMBAHASAN}

Tinggi Bibit Kelapa Sawit (cm)

Hasil sidik ragam menunjukkan bahwa pemberian pupuk urea berpengaruh nyata terhadap tinggi bibit kelapa sawit di akhir penelitian (11 MST), namun pemberian urine dan interaksinya berpengaruh tidak nyata terhadap tinggi bibit kelapa sawit (Tabel 1).

Tabel 1. Pengaruh pupuk urea, urine sapi dan interaksinya terhadap tinggi bibit kelapa sawit umur $11 \mathrm{MST}$.

\begin{tabular}{ccccc}
\hline Perlakuan & $\mathrm{P}_{0}$ & $\mathrm{P}_{1}$ & $\mathrm{P}_{2}$ & Rataan \\
\hline $\mathrm{U}_{0}$ & $18,33 \mathrm{a}$ & $19,67 \mathrm{a}$ & $19,67 \mathrm{a}$ & $19,22 \mathrm{a}$ \\
$\mathrm{U}_{1}$ & $19,00 \mathrm{a}$ & $18,67 \mathrm{a}$ & $20,33 \mathrm{a}$ & $19,33 \mathrm{a}$ \\
$\mathrm{U}_{2}$ & $19,67 \mathrm{a}$ & $16,67 \mathrm{a}$ & $23,33 \mathrm{a}$ & $19,89 \mathrm{a}$ \\
$\mathrm{U}_{3}$ & $18,67 \mathrm{a}$ & $19,00 \mathrm{a}$ & $21,33 \mathrm{a}$ & $19,67 \mathrm{a}$ \\
\hline Rataan & $18,92 \mathrm{a}$ & $18,50 \mathrm{a}$ & $21,17 \mathrm{~b}$ & \\
\hline
\end{tabular}

Keterangan: angka yang diikuti oleh huruf yang sama pada baris dan kolom yang sama menujukkan berbeda tidak nyata pada DMRT taraf 5\%. KK=12,80\%.

Dari Tabel 1 pemberian urine sapi $\left(\mathrm{U}_{2}\right)$ memiliki tinggi tanaman tertinggi yaitu $19,89 \mathrm{~cm}$, sedangkan $\mathrm{P}_{2}$ memiliki tinggi tanaman tertinggi yaitu $21,17 \mathrm{~cm}$. Interaksi pemberian pupuk urea dan urine sapi menunjukkan berbeda tidak nyata tetapi interaksi $\mathrm{P}_{2} \mathrm{U}_{2}$ memberikan tinggi tanaman tertinggi $23,33 \mathrm{~cm}$.

Pengaruh pemberian pupuk urea terhadap tinggi bihit kelana caxit umur 11 MCT nada Famhar 1

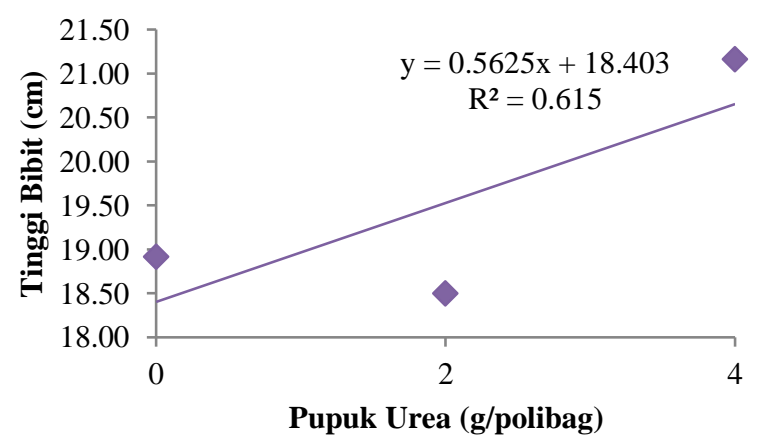

Gambar 1. Pengaruh pemberian pupuk urea terhadap tinggi bibit kelapa sawit umur $11 \mathrm{MST}$ 


\section{Luas Daun $\left(\mathrm{cm}^{2}\right)$}

Hasil sidik ragam menunjukkan bahwa pemberian pupuk urea, urine sapi dan interaksinya berpengaruh tidak nyata terhadap luas daun bibit kelapa sawit umur 11 MST (Tabel 2).

Tabel 2. Pengaruh pupuk urea, urine sapi dan interaksinya terhadap luas daun bibit kelapa sawit umur 11 MST.

\begin{tabular}{ccccc}
\hline Perlakuan & $\mathrm{P}_{0}$ & $\mathrm{P}_{1}$ & $\mathrm{P}_{2}$ & Rataan \\
\hline $\mathrm{U}_{0}$ & $57,70 \mathrm{a}$ & $73,39 \mathrm{a}$ & $61,60 \mathrm{a}$ & $64,23 \mathrm{a}$ \\
$\mathrm{U}_{1}$ & $64,19 \mathrm{a}$ & $64,70 \mathrm{a}$ & $69,50 \mathrm{a}$ & $66,13 \mathrm{a}$ \\
$\mathrm{U}_{2}$ & $68,57 \mathrm{a}$ & $81,42 \mathrm{a}$ & $85,47 \mathrm{a}$ & $78,48 \mathrm{a}$ \\
$\mathrm{U}_{3}$ & $59,57 \mathrm{a}$ & $60,76 \mathrm{a}$ & $72,71 \mathrm{a}$ & $64,35 \mathrm{a}$ \\
\hline Rataan & $62,50 \mathrm{a}$ & $70,07 \mathrm{a}$ & $72,32 \mathrm{a}$ &
\end{tabular}

Keterangan: angka yang diikuti oleh huruf yang sama pada baris dan kolom yang sama menujukkan berbeda tidak nyata pada DMRT taraf 5\%. KK=17,14\%.

Pada Tabel 2, dapat dilihat bahwa pemberian pupuk urea dan urine sapi terhadap luas daun tanaman umur 11 MST saling berbeda tidak nyata antar tiap taraf perlakuan. Pemberian urine sapi $\left(\mathrm{U}_{2}\right)$ memiliki luas daun tanaman tertinggi yaitu $78,48 \mathrm{~cm}^{2}$, sedangkan $\mathrm{P}_{2}$ memiliki luas daun tanaman tertinggi yaitu $72.32 \mathrm{~cm} 2$. Interaksi pemberian pupuk urea dan urine sapi menunjukkan berbeda tidak nyata pada seluruh kombinasi perlakuan walaupun menunjukkan berbeda tidak nyata perlakuan $\mathrm{P}_{2} \mathrm{U}_{2}$ memberikan luas daun tanaman tertinggi $85.47 \mathrm{~cm}^{2}$.

\section{Bobot Basah Bibit Kelapa Sawit (g)}

Hasil sidik ragam menunjukkan bahwa pemberian pupuk urea, urine sapi dan interaksinya berpengaruh tidak nyata terhadap bobot basah bibit kelapa sawit umur 11 MST (Tabel 3).

Tabel 3. Pengaruh pupuk urea, urine sapi dan interaksinya terhadap bobot basah bibit kelapa sawit umur $11 \mathrm{MST}$.

\begin{tabular}{ccccc}
\hline Perlakuan & $\mathrm{P}_{0}$ & $\mathrm{P}_{1}$ & $\mathrm{P}_{2}$ & Rataan \\
\hline $\mathrm{U}_{0}$ & $7,05 \mathrm{a}$ & $7,92 \mathrm{a}$ & $7,60 \mathrm{a}$ & $7,52 \mathrm{a}$ \\
$\mathrm{U}_{1}$ & $7,19 \mathrm{a}$ & $7,31 \mathrm{a}$ & $7,98 \mathrm{a}$ & $7,49 \mathrm{a}$ \\
$\mathrm{U}_{2}$ & $7,19 \mathrm{a}$ & $8,65 \mathrm{a}$ & $7,25 \mathrm{a}$ & $7,70 \mathrm{a}$ \\
$\mathrm{U}_{3}$ & $7,63 \mathrm{a}$ & $6,93 \mathrm{a}$ & $7,16 \mathrm{a}$ & $7,24 \mathrm{a}$ \\
\hline Rataan & $7,26 \mathrm{a}$ & $7,70 \mathrm{a}$ & $7,50 \mathrm{a}$ &
\end{tabular}

Keterangan: angka yang diikuti oleh huruf yang sama pada baris dan kolom yang sama menujukkan berbeda tidak nyata pada DMRT taraf $5 \%$. KK $=11,12 \%$.

Pada Tabel 3 dapat dilihat bahwa pemberian pupuk urea dan urine sapi terhadap berat basah tanaman umur 11 MST saling berbeda tidak nyata antar tiap taraf perlakuan. Pemberian urine sapi $\left(\mathrm{U}_{2}\right)$ memiliki berat basah tanaman tertinggi yaitu $7,70 \mathrm{~g}$, sedangkan $\mathrm{P}_{2}$ memiliki berat basah tertinggi yaitu $7,70 \mathrm{~g}$. Interaksi pemberian pupuk urea dan urine sapi menunjukkan berbeda tidak nyata pada seluruh kombinasi perlakuan walaupun menunjukkan berbeda tidak nyata perlakuan $\mathrm{P}_{1} \mathrm{U}_{2}$ memberikan berat basah tanaman tertinggi $8.65 \mathrm{~g}$.

\section{Bobot Kering Bibit Kelapa Sawit (g)}

Hasil sidik ragam menunjukkan bahwa pemberian pupuk urea, urine sapi dan interaksinya berpengaruh tidak nyata terhadap bobot kering bibit kelapa sawit umur 11 MST (Tabel 4).

Tabel 4. Pengaruh pupuk urea, urine sapi dan interaksinya terhadap bobot kering bibit kelapa sawit umur 11 MST.

\begin{tabular}{ccccc}
\hline Perlakuan & $\mathrm{P}_{0}$ & $\mathrm{P}_{1}$ & $\mathrm{P}_{2}$ & Rataan \\
\hline $\mathrm{U}_{0}$ & $2,02 \mathrm{a}$ & $2,24 \mathrm{a}$ & $2,24 \mathrm{a}$ & $2,17 \mathrm{a}$ \\
$\mathrm{U}_{1}$ & $2,03 \mathrm{a}$ & $2,17 \mathrm{a}$ & $2,26 \mathrm{a}$ & $2,15 \mathrm{a}$ \\
$\mathrm{U}_{2}$ & $2,08 \mathrm{a}$ & $2,69 \mathrm{a}$ & $2,32 \mathrm{a}$ & $2,36 \mathrm{a}$ \\
$\mathrm{U}_{3}$ & $2,62 \mathrm{a}$ & $2,08 \mathrm{a}$ & $2,02 \mathrm{a}$ & $2,24 \mathrm{a}$ \\
\hline Rataan & $2,19 \mathrm{a}$ & $2,30 \mathrm{a}$ & $2,21 \mathrm{a}$ &
\end{tabular}

Keterangan: angka yang diikuti oleh huruf yang sama pada baris dan kolom yang sama menujukkan berbeda tidak nyata pada DMRT taraf $5 \%$. KK= $13,32 \%$.

Pada Tabel 4 dapat dilihat bahwa pemberian pupuk urea dan urine sapi terhadap berat kering tanaman umur 11 MST saling berbeda tidak nyata antar tiap taraf perlakuan. Pemberian urine sapi $\left(\mathrm{U}_{2}\right)$ memiliki berat kering tanaman tertinggi yaitu $2,36 \mathrm{~g}$, sedangkan $\mathrm{P}_{1}$ memiliki berat kering tertinggi yaitu $2,30 \mathrm{~g}$. Interaksi pemberian pupuk urea dan urine sapi menunjukkan berbeda tidak nyata pada seluruh kombinasi perlakuan walaupun menunjukkan berbeda tidak nyata perlakuan $\mathrm{P}_{1} \mathrm{U}_{2}$ memberikan berat kering tanaman tertinggi 2,69 g.

\section{Pengaruh pemberian pupuk urea terhadap pertumbuhan bibit tanaman kelapa sawit di pembibitan awal}

Dari hasil penelitian dapat dilihat bahwa pemberian perlakuan dengan pupuk urea memberikan hasil yang nyata pada umur 11 MST, luas daun tidak nyata pada umur 11 MST, serta bobot basah dan kering tanaman tidak nyata pada umur 11 MST. Hasil yang yang tidak nyata ini disebabkan karena lambatnya daya serap akar terhadap beberapa unsur hara terutama $\mathrm{N}$ yang terdapat di pupuk urea. Hal ini dapat dilihat pada pendapat Sutedjo, (2012) bahwa unsur hara nitrogen sangat dibutuhkan untuk pertumbuhan bagian-bagian vegetatif tanaman seperti akar, batang dan daun, dan apabila ketersediaannya tidak cukup dapat menghambat pertumbuhan dan perkembangan tanaman. Setyati, (2008) menyatakan bahwa penambahan nitrogen yang cukup pada tanaman akan mempercepat laju pembelahan dan pemanjangan sel, pertumbuhan akar, batang dan daun berlangsung secara cepat. Diperjelas dengan pendapat Rosmarkam \& Yuwono, (2002) bahwa unsur hara N, P, $\mathrm{K}$ merupakan unsur hara esensial yang sangat besar peranannya dalam membantu proses pertumbuhan dan memperbaiki sifat fisik tanah serta meningkatkan aktivitas biologis tanah. Pada lampiran analisis tanah sebelum tanam dan 11 minggu setelah tanam dapat dilihat bahwa kandungan unsure hara yang terdapat pada media tanah dipolibag tersebut sangat rendah sekali sehingga tidak dapat meningkatkan pertumbuhan tanaman secara baik. Hal ini juga diperkuat oleh Leiwakabessy, (1997) mengatakan bahwa pertumbuhan dan perkembangan tanaman sangat dipengaruhi oleh unsur hara yang tersedia pertumbuhan akan maksimum jika unsur hara yang tersedia dalam keadaa optimum dan seimbang. Gardner et al., (1991) menyatakan bahwa unsur hara yang tersedia 
pada konsentrasi tertentu dapat meningkatkan pembentukan protein, karbohidrat dan lemak yang dibentuk tanaman dalam proses fotosintesis dan asimila digunakan oleh tanaman untuk pembentukan dan perkembangan sel baru. Pada analisis tanah tersebut juga dapat dilihat bahwa kandungan hara $\mathrm{P}$ sangat tinggi dalam media tanah tersebut sehingga dapat mempengaruhi pertumbuhan tanaman teruma tinggi tanaman pada umur 11 Minggu setelah tanam. Menurut Syarif, (1989) mengemukakan bahwa untuk tanaman tahunan, penambahan luas daun membutuhkan unsur hara yang seimbang dan berlanjut dalam waktu yang cukup lama. Hastuti, (2001) mengatakan fospor bagi tanaman bermanfaat untuk meningkatkan pertumbuhan, menambah jumlah daun, mempercepat pertumbuhan akar, mempercepat pembungaan.

\section{Pengaruh urine sapi terhadap pertumbuhan bibit tanaman kelapa sawit di pembibitan awal}

Dari hasil penelitian dapat dilihat bahwa pemberian urine sapi memberikan pengaruh yang tidak nyata pada semua parameter penelitian ini. Pada analisis urine sapi dapat dilihat bahwa kandungan hara N, C-org dan $\mathrm{C} / \mathrm{N}$ sangat rendah sekali sehingga tidak dapat membantu pertumbuhan bibit tanaman kelapa sawit. Hal ini disebabkan bahwa pemberian urine sapi sebagai bahan organik tidak mampu menambah unsur hara dan porositas tanah pada media tanam. Menurut Desiana et al., (2013) pemberian urin sapi berpengaruh pada variabel tinggi tanaman, jumlah daun, diameter batang, panjang akar, bobot segar tanaman dan bobot kering tanaman kakao. Sependapat dengan itu menurut Mulyani, (2002) apabila porositas tanah baik, maka keseimbangan turgor tanaman menjadi baik hal ini diperlukan untuk proses fotosintesis. Hasil fotosintesis akan banyak dimanfaatkan oleh tanaman untuk pertumbuhannya. Menurut Sarief, (1989) menyatakan bahwa penambahan bahan organik mempunyai nilai tertentu yaitu membentuk agregat agregat tanah yang baik dari partikelpartikel tanah. Salisbury \& Ross (1995) menyatakan bahwa penyerapan unsur hara terutama unsur hara nitrogen berpengaruh terhadap pembentukan luas daun.

Penelitian Alvi et al., (2018) melaporkan kandungan urin sapi memiliki $\mathrm{pH} 8,25$; N-total 0,23\%; $\mathrm{P}_{2} \mathrm{O}_{5} \quad 0,07 \%$; dan $\mathrm{K}_{2} \mathrm{O} 1,70 \%$ serta pemanfaatan urin ternak sebagai pupuk organik cair pada tanaman kelapa sawit dipembibitan utama tidak memberikan pengaruh terhadap pertumbuhan bibit kelapa sawit. Lubis \& Sjofjan, (2016) menyatakan bahwa pemberian urine sapi berpengaruh tidak nyata terhadap tinggi bibit, jumlah daun, diameter bonggol, volume akar, rasio tajuk akar, tetap berpengaruh nyata terhadap bobot kering bibit kelapa sawit dengan konsentrasi urin sapi $60 \%$ menunjukkan bobot kering tertinggi. Tetapi penelitian Arifianto et al., (2019) melaporkan sebaliknya bahwa pemberian urien sapi dosis $100 \mathrm{ml}$ sudah dapat meningkatkan pertumbuhan bibit kelapa sawit di prenursery yang sama baiknya dengan pupuk NPK. Ariyanti et al., (2018) melaporkan bahwa perlakuan urin sapi konsentrasi $200 \mathrm{ml} / \mathrm{l}$ air cenderung berpengaruh baik terhadap pertambahan jumlah daun bibit kelapa sawit.
Interaksi pupuk urea dan urine sapi terhadap pertumbuhan bibit tanaman kelapa sawit di pembibitan awal

Dari hasil penelitian dapat dilihat bahwa Interaksi pupuk urea dan urine sapi terhadap pertumbuhan vegetative bibit tanaman kelapa sawit (Elaeis guineensis Jacq) di pembibitan awal memberikan pengaruh yang tidak nyata pada semua paremeter pengamatan. Hal ini disebabkan karena perlakuan yang diberikan belum mampu mempengaruhi pola aktivitas fisiologi tanaman secara interval, walaupun diantara perlakuan yang diuji telah mampu mendukung pertumbuhan tanaman secara fisiologi.

Adapun hal lain yang menyebabkan tidak adanya pengaruh yang nyata terhadap seluruh parameter yang diamati diduga interaksi kedua perlakuan kurang saling mendukung satu sama lainnya, sehingga efeknya akar tanaman tidak respon dan ini sesuai dengan pendapat Marsono \& Sigit, (2001) menyatakan bahwa pertumbuhan tanaman yang baik dapat tercapai apabila faktor yang mempengaruhi pertumbuhan berimbang dan menguntungkan.

Dalam hal lain faktor luar dari tanaman itu sendiri kurang mendukung aktivitas dari kedua perlakuan, sebab kombinasi dari kedua perlakuan tertentu tidak selamanya akan memberikan pengaruh yang baik pada tanaman. Ada kalanya kombinasi tersebut akan mendorong pertumbuhan, menghambat pertumbuhan atau sama sekali tidak memberikan respon terhadap pertumbuhan dan perkembangan tanaman.

\section{KESIMPULAN}

Pemberian pupuk urea dapat meningkatkan pertumbuhan bibit tanaman kelapa sawit umur 11 MST. Pemberian urine sapi belum dapat meningkatkan pertumbuhan bibit tanaman kelapa sawit. Interaksi antara pemberian pupuk urea dan urine sapi belum dapat meningkatkan pertumbuhan vegetatif bibit kelapa sawit di pembibitan awal.

\section{DAFTAR PUSTAKA}

Alvi, B., Ariyanti, M., dan Maxiselly, Y. 2018. Pemanfaatan beberapa jenis urin ternak sebagai pupuk organik cair dengan konsentrasi yang berbeda pada tanaman kelapa sawit (Elaeis guineensis jacq.) di pembibitan utama. Kultivasi, 17(2), 622-627. https://doi.org/10.24198/kultivasi.v17i2.16914.

Anwar, E. K., dan Suganda, H. 2006. Pupuk limbah industri. Dalam Simanungkalit, R. D. M., D. A. Suriadikarta, R. Saraswati, D. Setyorini, dan W. Hartatik (Eds). Pupuk organik dan pupuk hayati. Badan Litbang Pertanian. p.83-112.

Arifianto, M., Hartati, R. M., dan Setyorini, T. 2019. Pengaruh dosis urine sapi dan waktu penyiraman terhadap pertumbuhan bibit kelapa sawit (Elaeis guineensis Jacq) di pre-nursery. Jurnal Agromast, 4(1), $11 \mathrm{p}$ http://36.82.106.238:8885/jurnal/index.php/JAI/artic le/view/903.

Ariyanti, M., Maxiselly, Y., Rosniawaty, S., dan 
Nilmawati, B. A. D. 2018. Pertumbuhan bibit kelapa sawit (Elaeis guineensis Jacq.) dengan aplikasi urin ternak sebagai pupuk organik. Agrosintesa Jurnal Ilmu Budidaya Pertanian, 1(2), 61-70. http://dx.doi.org/10.33603/.v1i2.1928.

Darmosarkoro, W., Sutarta, S. E., dan Winarna. 2007. Lahan dan pemupukan kelapa sawit. Pusat Penelitian Kelapa Sawit. Medan.

Desiana, C., Banuwa, I. S., Evizal, R., dan Yusnaini, S. 2013. Pengaruh pupuk organik cair urin sapi dan limbah tahu terhadap pertumbuhan bibit kakao (Theobroma cacao L.). Jurnal Agrotek Tropika, 1(1), 113-119. http://dx.doi.org/10.23960/jat.v1i1.1927.

Gardner, F. P., Pearce, R. B., dan R .L. Mitchell. 1991. Fisiologi Tanaman, UI Press: Jakarta.

Lingga dan Marsono. 2006. Petunjuk penggunaan pupuk. Penebar Swadaya. Jakarta.

Lubis, D. F., dan Sjofjan, J. 2016. Pengaruh pemberian sludge dan urin sapi terhadap pertumbuhan bibit kelapa sawit (Elaeis guineensis Jacq.) di pembibitan utama. JOM Faperta, 3(2), 1-12.

Marsono dan Sigit, P. 2001. Pupuk akar, jenis dan aplikasinya. Penebar Swadaya. Jakarta.

Mulyani, M. S. 2002. Pupuk dan cara pemupukan. Rineka Cipta: Jakarta.

Novizan. 2007. Petunjuk pemupukan yang efektif. PT Agro Media Pustaka. Jakarta.

Rosmarkam, A., dan Yuwono, N. W. (2002). Ilmu kesuburan tanah. Kanisius: Yogyakarta.

Salisbury, F. B., dan Ross, C. W. 1995. Fisiologi Tumbuhan. Diterjemahkan oleh Diah. R. Lukmana. ITB. Bandung.

Sarief, S. 1989. Kesuburan dan pemupukan tanah pertanian.Pustaka Buana, Bandung.

Sutedjo, M. M. 1999. Pupuk dan cara pemupukan. PT Rineka Cipta. Jakarta. 